\title{
MORPHOLOGICAL VARIATIONS OF GRACILARIA CHILENSIS BIRD, MCLACHLAN ET OLIVEIRA, 1986 (RHODOPHYTA, GRACILARIALES) IN THE SOUTHEAST PACIFIC
}

\author{
VARIACIONES MORFOLOGICAS DE GRACILARIA CHILENSIS BIRD, \\ MCLACHLAN ET OLIVEIRA, 1986 (RHODOPHYTA, GRACILARIALES) EN EL \\ PACIFICO SURESTE
}

\author{
Mario Edding, Cristina León \& Fadia Tala \\ Departamento de Biología Marina, Facultad de Ciencias del Mar, Universidad Católica del Norte, Casilla 117, \\ Coquimbo, Chile. E-mail: medding@ucn.cl
}

\begin{abstract}
The present work is a population morphometric study of Gracilaria from different environments along a latitudinal gradient of the Chilean coast that cover $1,500 \mathrm{~km}$. Gracilaria species have been extensively exploited with an average extraction of 75,000 t per year. In Chile this seaweed is usually found in sandy bottom bays between Antofagasta $\left(23^{\circ} 29^{\prime} \mathrm{S}-70^{\circ} 25^{\prime} \mathrm{W}\right)$ and Chiloé $\left(42^{\circ} 03^{\prime} 0^{\prime \prime} \mathrm{S}-73^{\circ} 11^{\prime} 0^{\prime \prime} \mathrm{W}\right)$. Observations were made in 51 plants. Macroscopic observations were done in fresh plants, microscopic characters were determined in transversal sections with $20 \%$ Karo syrup and stained with aniline blue. Numerical analyses were performed by one-way ANOVA and Principal Component Analysis. The latter analysis was performed for those characters with significant differences among the localities: basal constriction of branches, branch frequency, cortex cell diameter, subcortex cell diameter, thickness of the cortex and medullar cell diameter. The results of the Principal Component Analysis showed that $61 \%$ of the variance corresponded to the two first components. There were not observed groups clearly defined. The data suggest that along the coast of Chile there is only one morphotype that corresponds to the description of Gacilaria chilensis Bird, McLachlan et Oliveira, 1986 and it fits to the bulk of the material utilized in commercial production.
\end{abstract}

KEYwords: Gracilaria chilensis, seaweed, morphology, Chile.

\section{RESUMEN}

Este trabajo es un estudio morfológico de poblaciones de Gracilaria que habitan diferentes ambientes a lo largo de una gradiente latitudinal de la costa de Chile que cubre $1.500 \mathrm{Km}$. La especies de Gracilaria han sido extensivamente explotadas, con promedios de extracción de 75.000 toneladas anuales. El alga se encuentra en bahías de fondos arenosos, entre Antofagasta ( $\left.23^{\circ} 29^{\prime} \mathrm{S}-70^{\circ} 25^{\prime} \mathrm{W}\right)$ y Chiloé $\left(42^{\circ} 03^{\prime} 0^{\prime \prime} \mathrm{S}-7^{\circ} 11^{\prime} 0^{\prime}\right.$ 'W). Fueron analizadas 51 plantas. Se realizaron observaciones macroscópicas en plantas frescas. Los caracteres microscópicos se determinaron en secciones teñidas con azul de anilina y montadas en una solución de miel Karo al 20\%. Los análisis numéricos de los datos se realizaron mediante un ANOVA de una vía y un Análisis de Componentes Principales. Este último análisis se realizó para aquellos caracteres con diferencias significativas entre localidades: constricción basal de las ramificaciones, frecuencia de la ramificación, diámetro de las células de la corteza, diámetro de las células subcorticales, grosor de la corteza y diámetro de las células de la médula. Los resultados del Análisis de Componentes Principales mostraron que el $61 \%$ de la varianza correspondió a los 2 primeros componentes. No se observaron grupos claramente definidos. Los datos encontrados sugieren que a lo largo de la costa estudiada existe un solo morfotipo que corresponde a la descripción de Gracilaria chilensis Bird, McLachlan et Oliveira, 1986 y esta descripción concuerda con la mayoría del material que se emplea para un uso comercial.

PalabRas Claves: Gracilaria chilensis, algas marinas, morfología, Chile. 
Morphological variations of Gracilaria chilensis: EDDING, M. ET AL.

\section{INTRODUCTION}

The genus Gracilaria Greville 1830 is distributed in areas with temperate and tropical waters and it is possible to find intertidal and subtidal populations (Bird et al. 1977). The species of this genus are highly polymorphics with variable sizes and ramifications. Therefore, several specific names have been misplaced or certain specific characters were poorly defined (Abbott 1983). Gracilaria has been extensively exploited along the Chilean coast with an average extraction of 75,000 t per year (Anuario Estadístico de Pesca, 2001). The development of Gracilaria management strategies and establishment of over 500 farming centers sustain the high production of this seaweed with important revenues for Chile (Buschmann et al. 2001).

Along the Chilean coast, Gracilaria was represented by several species. Etcheverry (1958) reported Gracilaria lemaneiformis (Bory) Weber von Bosse [now Gracilariopsis lemaneiformis (Weber von Bosse) Dawson, Acleto et Foldvik] in Chiloé. Levring (1960) informed the presence of Gracilaria confervoides (Linnaeus) Greville [now Gracilaria gracilis (Stackhouse) Steentoft, Irvine et Farnham], Gracilaria peruana Piccone et Grunow, and Gracilaria pulvinata Skottsberg. Later, Kim (1970) communicated the name of five species of Gracilaria: Gracilaria verrucosa (Hudson) Papenfuss [now G. gracilis]; G. lemaneiformis, Gracilaria edulis (Gmelin) Silva [now Hydropuntia edulis (S.G. Gmelin) Gurgel \& Fredericq, 2004], G. peruana, and G. pulvinata. Bird et al. (1986) described Gracilaria chilensis Bird, McLachlan et Oliveira as the result of carpospores cultured from plants of La Herradura Bay, Coquimbo (29 $53^{\circ} \mathrm{S}$ $71^{\circ} 18^{\prime} \mathrm{W}$ ) and Maullín, Puerto Montt ( $41^{\circ} 30^{\prime} \mathrm{S}-$ $\left.73^{\circ} 50^{\prime} \mathrm{W}\right)$. From these records it is important to mention that G. peruana has been not reported again as components of the Chilean flora. In northern Chile there is G. chilensis and in the southern Chilean coast G. verrucosa, although several studies (Bird et al. 1986, Candia, 1988, Möller \& Westermeier 1988, Santelices \& Ugarte 1990) presume the existence of G. chilensis also in southern Chile. Nevertheless, molecular analysis of nuclear and plastidial DNA verified that the different morphotypes found for Gracilaria in Chilean coast corresponded to G. chilensis (González et al. 1996, Meneses 1996, Candia et al. 1999).
The present work is a population morphometric study of Gracilaria species along the Chilean latitudinal gradient which analyzes plants from different environments where anatomical and morphological variations may exist. The morphometric analysis is a good complement of the molecular one (Muller et al. 1998) as it was demonstrated in the work with Gracilaria by Liao and Homersand (2003). This study was made between 1985 and 1991 before the global knowledge and availability of molecular techniques to investigate the algal systematic. Therefore the hypothesis was that the only species utilized in aquaculture along the coast of Chile is $G$. chilensis. The goals of this study were to evaluate the morphometric variations of some taxonomical characters in natural population of Gracilaria; to discriminate probable existence of morphological groups; and to determine the relative taxonomical weight of each character.

\section{MATERIAL AND METHODS}

\section{Study AREA}

The biological material was collected from 4 zones along the Chilean coast: Coquimbo (29 $58^{\prime} 55^{\prime \prime} \mathrm{S}$ $\left.71^{\circ} 22^{\prime} 20^{\prime \prime} \mathrm{W}\right)$, Concepción (36 $45^{\circ} 50^{\prime}$ 'S -

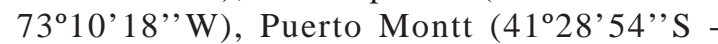
$\left.72^{\circ} 57^{\prime} 25^{\prime \prime} \mathrm{W}\right)$ and Chiloé (41 $\left.51^{\circ} \mathrm{\prime} \mathrm{S}-73^{\circ} 47^{\prime} \mathrm{W}\right)$ between 1985 and 1991 (Fig. 1). In each zone the seaweeds were collected according to Table I. 51 plants were selected for the study.

\section{Character measurements}

The measured characters (Table II) were done following Renfrew (1983). Each character was measured 10 times in the same plant except for characters 3 and 4 that correspond to the degree of ramification. Plants were stored in the herbarium of the Department of Marine Biology, Universidad Católica del Norte in Coquimbo, Chile (UCN 00093-00180). Observations and measurements of macroscopic characters were done in fresh plants. Microscopic characters of vegetative and reproductive structures were determined in transversal sections stained with aniline blue and mounted in $20 \%$ Karo syrup (Best Foods C.P.C. International Inc.) 


\section{NUMERICAL ANALYSIS.}

Each morphological character (Table II) was measured ten times from the same individual plant. The data were analyzed by a one-way ANOVA $(95 \%$ of confidence limit) after the check of variance homogeneity by Bartlett test (Sokal \& Rohlf, 1981). Once the hypothesis was rejected the data were transformed according to $(\mathrm{X}+0.5) 1 / 2$. Characters that separated the major groups were entered to a Principal Component Analysis. The software utilized for the analysis was Statgraphics (STSC, Inc. 1991).

TABLE I. Gracilaria specimens, information on localities, collecting period, number of plants, and plant reproductive state.

TABLA I. Gracilaria, información de localidades, períodos de colecta, número de plantas y fenología.

\begin{tabular}{|c|c|c|}
\hline ZONE/ LOCALITY & DATE & $\mathrm{N}^{\circ} \operatorname{PLANTS}(*)$ \\
\hline \multicolumn{3}{|l|}{ COQUIMBO } \\
\hline \multirow[t]{2}{*}{ Herradura Bay $\left(29^{\circ} 58^{\prime} 55^{\prime} ’ \mathrm{~S}-71^{\circ} 22^{\prime} 20^{\prime \prime} \mathrm{W}\right)$} & Mar, Jun and Sep, 1986 & $3(1)$ \\
\hline & Jan and Mar, 1988 & $16(2)$ \\
\hline \multicolumn{3}{|l|}{ CONCEPCIÓN } \\
\hline Lenga $\left(36^{\circ} 45^{\prime} 50^{\prime \prime} \mathrm{S}-73^{\circ} 10^{\prime} 18^{\prime \prime} \mathrm{W}\right)$ & Oct, 1985 & $7(1)$ \\
\hline Tubul, Gulf of Arauco ( $\left.37^{\circ} 14^{\prime} \mathrm{S}\right)$ & Mar and Jul, 1991 & $2(2)$ \\
\hline \multicolumn{3}{|l|}{ PUERTO MONTT } \\
\hline 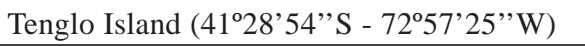 & Apr, 1988 & $8(2)$ \\
\hline \multicolumn{3}{|l|}{ CHILOÉ } \\
\hline 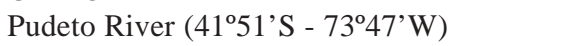 & Aug and Oct, 1987 & $2(2)$ \\
\hline Quempillén $\left(41^{\circ} 52^{\prime} \mathrm{S}-73^{\circ} 46^{\prime} \mathrm{W}\right)$ & Aug and Oct, 1987 & $1(1)$ \\
\hline \multirow[t]{2}{*}{ Putemún $\left(42^{\circ} 29^{\prime} 22^{\prime}{ }^{\prime} \mathrm{S}-73^{\circ} 45^{\prime} 27^{\prime \prime} \mathrm{W}\right)$} & Aug and Oct, 1987 & $9(2)$ \\
\hline & Apr, 1991 & $3(2)$ \\
\hline
\end{tabular}

* (1) Cistocarpic; (2) Tetrasporic

\section{RESULTS}

1. Morphometric analysis in a latitudinal gradient. In Gracilaria plants used for the study, 11 were cystocarpic and 40 tetrasporic. Male plants were observed once in the Río Tubul estuary, Gulf of Arauco.

From 21 measured characters, only six of them presented significant differences among the localities. They were: (\# 1) the basal constriction of branches; (\# 3) branch frequency; (\# 9) cortex cell diameter; (\# 10) subcortex cell diameter; (\# 11) thickness of the cortex and (\# 12) medullar cell diameter (See Table III).

Basal constriction of branches (\# 1) in plants from Concepción was significantly $(\mathrm{p}<0.05)$ greater than the other localities (Table III). Branch frequency (\# 3) showed significant variation (p $<0.05$ ) between the plants from Puerto Montt and Chiloé, when compared to those from Coquimbo and Concepción (average values < 1) (Table III). Cortex cell diameter (\# 9) in plants from Concepción and Puerto Montt showed smaller values $(\mathrm{p}<0.05)$ than Coquimbo and Chiloé, and subcortex cell diameter (\# 10) from Concepción was lower than other localities (Table III). The thickness of the cortex (\# 11) evidenced a latitudinal variation with a gradual increase towards the south (Table III). The observed medullar cell diameter (\# 12) showed that southern localities (Puerto Montt and Chiloé) have lower values than Concepción and Coquimbo (Table III). 
Morphological variations of Gracilaria chilensis: EDDING, M. ET AL.

TABLE II. Description of microscopic and macroscopic characters utilized for the morphological evaluation of Gracilaria specimens. The number of each character represents the authentication code.

TABLA II. Descripción de caracteres macroscópicos y microscópicos empleados para la evaluación morfológica de las plantas de Gracilaria. El número de cada carácter representa el código de verificación.

\section{MACROSCOPIC CHARACTERS}

1. Basal constriction of branches (mm)

2. Branch apex width (mm)

3. Branch frequency $\left(n^{\circ}\right)$

4. Degree of branching $\left(n^{o}\right)$

5. Outer branch angles $\left({ }^{\circ}\right)$

6. Inner branch angle $\left({ }^{\circ}\right)$

7. Flattening at the forks (mm)

8. Flattening at mid branch (mm)

9. Cortical cell diameter $(\mu \mathrm{m})$

10. Second cortical layer cell diameter $(\mu \mathrm{m})$

11. Thickness of cortex $\left(\mathrm{n}^{\circ}\right)$

12. Medullar cell diameter $(\mu \mathrm{m})$

13. Tetrasporangium length $(\mu \mathrm{m})$

14. Tetrasporangium width $(\mu \mathrm{m})$

15. Cystocarp width $(\mu \mathrm{m})$

16. Cystocarp height $(\mu \mathrm{m})$

17. Basal constriction of cystocarp $(\mu \mathrm{m})$

18. Thickness of pericarp $\left(n^{\circ}\right)$

point.

\section{DESCRIPTION}

Ratio of the branch width at its base to the width half way to the next fork was determined.

Width of a branch taken $5 \mathrm{~mm}$ from the apex.

Most branched apex was determined. For this axis a ratio between the number of branches and the length from the base of the plant to the tip of the axis was calculated.

Number of times the best-developed axis of the plant branched.

Ratio of the two abaxial angles at branch point was determined.

Angle between the branch and main axis.

Ratio of the width of the thallus fork to its thickness was measured.

Same as above was measured half a way between two forks.

Diameter of the outermost cortical cell was taken perpendicular to the thallus surface.

Diameter of the second cortical layer.

Number of cortex cell layers.

Diameter along the longest axis of the cell.

Length of intact tetrads was taken along their longest axis.

Width perpendicular to the length.

Measured at the widest point from median sections.

The height was determined from the base of the gonimoblast to the tip of the ostiole.

Width of the cystocarp at its base.

Number of cell layers taken from a median section of a mature cystocarp at the widest 
Gayana 70(2), 2006

Continuation Table II.

\begin{tabular}{ll}
\hline MACROSCOPIC CHARACTERS & DESCRIPTION \\
\hline 19. Diameter of pericarp cells (ìm) & $\begin{array}{l}\text { Diameter of pericarp cells was measured from } \\
\text { the outermost, through to the innermost layers. }\end{array}$ \\
20. Width of gonimoblast cells (ìm) & $\begin{array}{l}\text { Width of the widest point and perpendicular to } \\
\text { the length was found. }\end{array}$ \\
21. Length of gonimoblast cells (ìm) & $\begin{array}{l}\text { Length was taken along the longest axis of } \\
\text { gonimoblast cells. }\end{array}$
\end{tabular}

TABLE III. Morphometric summary and ANOVA $(* p<0.05 ; * * p<0.01)$ of the analyzed characters of Gracilaria specimens collected in Coquimbo, Concepción, Puerto Montt and Chiloé. Values without standard deviation correspond to 1 sample.

TABLA III. Resumen de la morfometría y ANDEVA $(* p<0.05 ; * * p<0.01)$ de los caracteres analizados en la plantas de Gracilaria recolectadas en Coquimbo, Concepción, Puerto Montt y Chiloé. Los valores sin desviación estándar corresponden a 1 muestra.

\begin{tabular}{|c|c|c|c|c|c|c|}
\hline \multirow[t]{2}{*}{ Code $\mathrm{N}^{\mathrm{o}}$} & \multirow[t]{2}{*}{ Coquimbo } & \multirow[t]{2}{*}{ Concepción } & \multirow[t]{2}{*}{ Puerto Montt } & \multirow[t]{2}{*}{ Chiloé } & \multicolumn{2}{|c|}{ ANOVA } \\
\hline & & & & & $\mathrm{F}_{\text {(d.f.) }}$ & $p$ \\
\hline $1(\mathrm{~mm})$ & $1.354 \pm 0.163$ & $1.558 \pm 0.248$ & $1.414 \pm 0.140$ & $1.277 \pm 0.203$ & $3.79_{(3,45)} \quad 0$ & $0.0164 *$ \\
\hline $2(\mathrm{~mm})$ & $0.233 \pm 0.076$ & $0.181 \pm 0.056$ & $0.170 \pm 0.046$ & $0.222 \pm 0.045$ & $1.88_{(3,45)}$ & 0.1452 \\
\hline $3(\mathrm{~N} / \mathrm{cm})$ & $0.905 \pm 0.373$ & $0.680 \pm 0.390$ & $3.263 \pm 0.458$ & $1.912 \pm 0.810$ & $40.09_{(3,44)}$ & $<0.01 * *$ \\
\hline $4\left(\mathrm{~N}^{\mathrm{o}}\right)$ & $3.526 \pm 0.512$ & $3.142 \pm 0.377$ & $3.625 \pm 0.517$ & $3.500 \pm 0.500$ & $1.38_{(3,45)}$ & 0.2605 \\
\hline $5\left(^{\circ}\right)$ & $0.857 \pm 0.075$ & $0.816 \pm 0.082$ & $0.815 \pm 0.053$ & $0.881 \pm 0.061$ & $2.29_{(3,45)}$ & 0.0902 \\
\hline $6\left(^{\circ}\right)$ & $54.32 \pm 8.56$ & $58.00 \pm 10.44$ & $54.09 \pm 6.37$ & $51.06 \pm 5.33$ & $1.39_{(3,45)}$ & 0.2649 \\
\hline $7(\mathrm{~mm})$ & $1.195 \pm 0.118$ & $1.214 \pm 0.114$ & $1.276 \pm 0.120$ & $1.288 \pm 0.193$ & $1.36_{(3,45)}$ & 0.2660 \\
\hline $8(\mathrm{~mm})$ & $0.926 \pm 0.306$ & $0.998 \pm 0.009$ & $1.000 \pm 0.001$ & $1.277 \pm 0.203$ & $0.57_{(3,45)}$ & 0.6362 \\
\hline $9(\mu \mathrm{m})$ & $13.04 \pm 0.05$ & $10.81 \pm 0.06$ & $10.69 \pm 0.06$ & $12.10 \pm 0.08$ & $5.47_{(3,45)} \quad 0$ & $0.0027 * *$ \\
\hline $10(\mu \mathrm{m})$ & $18.90 \pm 0.25$ & $13.16 \pm 0.18$ & $23.12 \pm 0.16$ & $20.31 \pm 0.19$ & $4.35_{(3,45)} \quad 0$ & $0.0089 * *$ \\
\hline $11\left(\mathrm{~N}^{\mathrm{o}}\right)$ & $1.18 \pm 0.29$ & $1.43 \pm 0.53$ & $1.88 \pm 0.58$ & $1.80 \pm 0.82$ & $4.35_{(3,45)} \quad 0$ & $0.0089 * *$ \\
\hline $12(\mu \mathrm{m})$ & $259.1 \pm 1.51$ & $318.9 \pm 1.15$ & $117.9 \pm 0.36$ & $170.7 \pm 0.35$ & $6.49_{(3,43)} \quad 0$ & $0.0010 * *$ \\
\hline $13(\mu \mathrm{m})$ & $41.36 \pm 0.23$ & - & $37.71 \pm 0.26$ & $35.05 \pm 0.30$ & $3.11_{(2,35)} \quad 0$ & 0.0569 \\
\hline $14(\mu \mathrm{m})$ & $32.05 \pm 0.31$ & - & $29.47 \pm 0.12$ & $29.76 \pm 0.41$ & $0.36(2,35)$ & 0.0699 \\
\hline $15(\mu \mathrm{m})$ & $1,940 \pm 2.639$ & $1,560 \pm 3.681$ & - & 1,168 & $0.05(2,8)$ & 0.9502 \\
\hline $16(\mu \mathrm{m})$ & $824.6 \pm 1.837$ & $891.4 \pm 2.730$ & - & 1,220 & $0.23(2,7)$ & 0.7944 \\
\hline $17(\mu \mathrm{m})$ & $751.3 \pm 1.344$ & $683.0 \pm 0.846$ & - & 497.0 & $2.45(2,8)$ & 0.1473 \\
\hline $18\left(\mathrm{~N}^{\mathrm{o}}\right)$ & $8.833 \pm 0.763$ & $7.833 \pm 1.602$ & - & 8.5 & $0.52(2,7)$ & 0.6131 \\
\hline $19(\mu \mathrm{m})$ & $13.13 \pm 0.14$ & $13.68 \pm 0.24$ & - & 13.84 & $0.01(2,7)$ & 0.9890 \\
\hline $20(\mu \mathrm{m})$ & $45.13 \pm 0.47$ & $27.50 \pm 0.41$ & - & 44.36 & $2.89(2,7)$ & 0.1213 \\
\hline $21(\mu \mathrm{m})$ & $23.84 \pm 0.45$ & $18.28 \pm 0.37$ & - & 29.97 & $0.68(2,7)$ & 0.5328 \\
\hline
\end{tabular}


Morphological variations of Gracilaria chilensis: EDDING, M. ET AL.

2. Relative taxonomical weight of the characters. The result of the Principal Component Analysis (Table IV) showed that $61 \%$ of the variance is within the two first components, basal constriction of branches and cortex cell diameter. When these components were graphically represented no groups were defined related to the latitudinal gradient.

TABLE IV. Principal Component Analysis for 5 characters analyzed in Gracilaria: (1) basal constriction of branches, (2) cortex cell diameter, (3) subcortex cell diameter, (4) cortex thickness, and (5) medullar cell diameter.

TABla IV. Análisis de Componentes Principales para 5 caracteres analizados en Gracilaria: (1) contricción basal de la ramificación, (2) diámetro de las células corticales, (3) diámetro de las células subcorticales, (4) grosor de la corteza, y (5) diámetro de las células medulares.

\begin{tabular}{ccc}
\hline No COMPONENT $^{\circ}$ & \% VARIANCE & \% CUMULATIVE \\
\hline 1 & 31.69 & 31.69 \\
2 & 29.20 & 60.89 \\
3 & 18.49 & 79.38 \\
4 & 12.35 & 91.74 \\
5 & 8.25 & 100.00 \\
\hline
\end{tabular}

\section{DISCUSSION}

The morphology of Gracilaria populations along the Pacific coast of Chile has been scarcely documented. The presence of few specimens bearing reproductive structures (Kim 1970, Black \& Fonck 1981, Fonck 1986, Pizarro 1986, Edding et al. 1987), high degree of phenotypic plasticity within the genus (Bird et al. 1977, Bird \& McLachlan 1982, Abbott 1983, Bird $\&$ McLachlan 1984), and massive transplants with commercial purposes have generated confusion (Kim 1970, Bird et al. 1986) and made difficult a precise description of the species.

The existence of Gracilaria verrucosa (now $G$. gracilis) in the Pacific coast of Chile (Etcheverry 1958, Kim 1970, Kim \& Candia 1977, Romo et al. 1979, Bird et al. 1986) is doubtful. Kim (1970) and Kim \& Candia (1977) erroneously denominated $G$. verrucosa to plants with textorii type of spermatangia giving more importance to external vegetative characters. Between G. chilensis and G. verrucosa there are main differences that allowed Bird et al. (1986) to state that $G$. verrucosa is not part of the Chilean marine flora. Bird \& McLachlan (1982) suggested that $G$. verrucosa from Chile correspond to plants that were incorrectly named. In this study, plants bearing verrucosa type of spermatangia and nutritive filaments, and connecting pericarp and gonimoblast were not observed, confirming the observed by Bird \& McLachlan (1982).
The presence of Gracilaria lemaneiformis along the Chilean coast has been recorded by Etcheverry (1958), Kim (1970), Kim \& Candia (1977), Romo et al. (1979), Bird et al. (1986) and Santelices (1989). Nevertheless, any of these authors described the cystocarp or spermatangia. Fredericq \& Hommersand (1989) transferred this species to the genus Gracilariopsis. Two characters are the key to its determination: absence of nutritive filaments in the cystocarp; and chorda type of superficial spermatangia. Kim (1970) reported plants with chorda type of spermatangia from Río Tubul to indicating the presence of male plants with textorii type of spermatangia. Gracilariopsis lemaneiformis for Chile was latter registered by Ramírez \& Tapia (1991) for Antofagasta ( $24^{\circ} 22^{\prime} \mathrm{S}-70^{\circ} 32^{\prime} \mathrm{W}$ ) giving a geographical range from Paita, Perú to Antofagasta. Candia (1988) and Möller \& Westermeier (1988) reported Gracilaria chilensis in southern Chile without mentioning the presence of nutritive filaments, as is observed in the present work. This may be related to the variability of the character (Papenfuss 1967, Yamamoto 1978, Bird \& McLachlan 1984, Oliveira 1984, Bird \& Rice 1990). Searles et al. (1974) collected seaweeds by scuba dive during two consecutive years (Hero cruises 72 and 73) from Puerto Montt to Statten Island and they did not find Gracilaria specimens (R. Searles, pers. com.).

The phylogeny and systematic analyses of Family 
Gracilariaceae from Atlantic and Pacific coast based on small subunit rDNA and its sequences (Bellorin et al. 2002), suggest that the main divergences in Gracilaria are related more to geographic isolation than to broad morphological differences. The Pacific species includes G. chilensis and G. tenuistipitata, which appear to be closely related entities, both slender and terete with textorii type spermatangial configuration despite their different respective habitats of cold and warm water (Bellorin et al. 2002).

The existence of few plants with reproductive structures, mainly male plants; the high degree of phenotypic plasticity in the genus and the massive transplant of Gracilaria that occurred in Chile as a consequence of the commercial cultivation, have generated a degree of confusion in the taxonomy of this genus. The results of this study do not establish a morphological variation that permits determining morphological groups. The variations observed in the characters: branch basal constriction, branch frequency, cortex cell diameter, subcortex cell diameter and thickness of the cortex may correspond to local phenotypical variations due to environmental or biological forces or according to Chapman et al. (1977), whom observed similar characters, to seasonal changes. The Principal Component Analysis confirms that the observed morphological differences are not consistent and they do not have taxonomical value. The morphological homogeneity of the examined characters defined the presence of only one morphotype that conforms with the description of Gracilaria chilensis. In conclusion, utilizing traditional morphometric techniques we conclude that $G$. chilensis is the main species of Gracilaria present along the Chilean coast. Similar results have been reported after this study by using molecular techniques (González et al. 1996, Meneses 1996, and Candia et al. 1999). The results confirm the distribution of G. chilensis extending its southern range down to Chiloé. Hoffmann \& Santelices (1997) found G. chilensis in the coast of Coihaique $\left(45^{\circ} \mathrm{S}\right)$ mainly due to an introduction for aquaculture.

\section{ACKNOWLEDGMENTS}

We would like to thanks Dr. Jack McLachlan for his support and enthusiasm in giving us insight in this study. This study was part of the requirements that the second author fulfilled to obtain her Marine Biology degree in 1990. This research was kindly supported by a grant given by Universidad Católica del Norte to the first author. This manuscript was finished during a stay in the Port Erin Marine Laboratory, University of Liverpool under the generous support of the British Council. Also, we thanks to Dr. Funyi Chow for the language brush up and to the referees for their helpful comments.

\section{BIBLIOGRAPHY}

Аввотт, I. 1983. Some species of Gracilaria (Rhodophyta) from California. Taxon 32: 561-564.

Anuario Estadístico de Pesca 2005. Servicio Nacional de Pesca (SERNAPESCA) Ministerio de Economía, Fomento y Reconstrucción, Chile. 307 p.

Bellorin, A., M. Oliveira \& E. Oliveira. 2002. Phylogeny and systematics of the marine algal family Gracilariaceae (Gracilariales, Rhodophyta) based on small subunit rDNA and its sequences of Atlantic and Pacific species. J. Phycol. 38: 551563.

Bird, N., J. McLachlan \& D. Grund. 1977. Studies on Gracilaria. In vitro life history of Gracilaria sp. from the Maritime Provinces. Can. J. Bot. 55: 1282-1990.

BiRd, C. J. \& J. McLachlan. 1982. Some underutilized taxonomic criteria in Gracilaria (Rhodophyta, Gigartinales). Bot. Mar. 25: 557-562.

BiRD, C.J. \& J. MCLAChlan. 1984. Taxonomy of Gracilaria: evaluation of some aspects of reproductive structure. Proc. Int. Seaweed Symp. 11: 41-46.

Bird, C. J., J. McLachlan \& E. Oliveira. 1986. Gracilaria chilensis sp. nov. (Rhodophyta, Gigartinales), from Pacific South America. Can. J. Bot. 64: 29282948.

BIRD, C.J. \& E.L. Rice. 1990. Recent approaches to the taxonomy of the Gracilariaceae (Gracilariales, Rhodophyta) and the Gracilaria verrucosa problem. Hydrobiologia 204/205: 111-118.

BlaCK, H.J. \& E. FONCK. 1981. On the vegetation dynamics of Gracilaria sp. in playa Changa, Coquimbo, Chile. Proc. Int. Seaweed Symp. 10: 223-228.

Buschmann A., J. Correa, R. Westermeier, M. HernándeZGonzÁlez \& R. Norambuena. 2001. Red algal farming in Chile: a review. Aquaculture 194: $203-$ 220.

CAndia, A. 1988. Ciclo reproductivo “in vitro" de dos poblaciones de Gracilaria Greville (Rhodophyta; Gracilariaceae) de Lenga. Bahía de San Vicente. Gayana Bot. 45: 357-364.

Candia, A., M. González, B. Montoya, P. Gómez \& W. NELSON. 1999. Comparison of ITS RFLP patterns of Gracilaria (Rhodophyceae; Gracilariales) 
Morphological variations of Gracilaria chilensis: EDDING, M. ET AL.

populations from Chile and New Zealand and an examination of interfertility of Chilean morphotypes. J. Appl. Phycol. 11: 185-193.

Chapman, A., T. Eldelstein \& P. Power. 1977. Studies on Gracilaria. I. Morphological and anatomical variation in samples from the lower Gulf of St. Lawrence and New England. Bot. Mar. 20: 149153.

Edding, M., C. León \& R. AmbleR. 1987. Growth of Gracilaria sp. in the laboratory. Hydrobiologia 151/152: 375-379.

EtcheVERry, H. 1958. Algas marinas chilenas productoras de ficocoloides. Rev. Biol. Mar. (Chile). 8: 153-174.

Fonck, E. 1986. Situación del recurso Gracilaria en la región de Coquimbo, Chile. En: K. Alveal, A. Candia, I. Inostroza, A. Pizarro, A. Poblete and H. Romo, (eds.). Manejo y Cultivo de Gracilaria en Chile. Memorias Seminario-Taller, Universidad de Concepción, Concepción, Chile.

FredericQ, S. \& M. H. Hommersand. 1989. Comparative morphology and taxonomic status of Gracilariopsis (Gracilariales, Rhodophyta). J. Phycol. 25: 228-241.

González, M., R. Montoya, A. Candia, P. Gómez \& M. Cisternas. 1996. Organellar DNA restriction fragment length polymorphism (RFLP) and nuclear random amplified polymorphic DNA (RAPD) analyses of morphotypes of Gracilaria (Gracilariales, Rhodophyta) from Chile. Hydrobiologia 326/327: 229-234.

Gurgel, C.F.D. \& FredericQ, S. (2004). Systematics of the Gracilariaceae (Gracilariales, Rhodophyta) : a critical assessment based on $r b c \mathrm{~L}$ sequence analysis. J. Phycol. 40: 138-159.

Hoffmann A. \& B. Santelices. 1997. Flora Marina de Chile Central. Pontificia Universidad Católica de Chile, Santiago. $434 \mathrm{p}$

KIM, D. H. 1970. Economically important seaweeds in Chile. I. Gracilaria. Bot. Mar. 13:140-162.

KIM, D. H. \& A. CANDIA. 1977. Una nota sobre el cultivo unialgal de Gracilaria procedente de la Isla Santa María y Río Tubul, Provincia de Arauco. Boletin Sociedad de Biología (Concepción, Chile) 51: 107-112.

LEVRING, T. 1960. Contributions to the marine algal flora of Chile. Lund. Univ: Arsskr., n.f., Avd. 2, 56(10): 1- 84.

LiaO, L.M. \& M.H. Hommersand. 2003. A morphological study and taxonomic reassessment of the genritype species in the Gracilariaceae. J. Phycol. 39: 120-1232.
Meneses, I. 1996. Assessment of populations of Gracilara chilensis (Gracilariales, Rhodophyta) utilizing RADP. J. appl.Phycol. 8: 185-192.

Möller, P. \& R. Westermeier. 1988. Cultivo de Gracilaria chilensis (Rhodophyta, Gigartinaceae) en condiciones de laboratorio. Gayana. Bot. 45: 305-308.

Muller K.M., R.G. Sheath, M.L. Vis, T.J. Crease \& K.M. Cole. 1998. Biography and Systematic of Bangia (Bangiales, Rhodophyta) based on Rubisco spacer, rbcl gene and 18S rRNA gene sequence and morphometric analysis. 1. North America. Phycologia 37(3): 195-207.

Oliveira, E. C. 1984. Taxonomic criteria in the genus Gracilaria Grev. (Rhodophyta): an experience with the Atlantic species. Proc. Int. Seaweed Symp. 11: 55-58.

PAPENFuss, G. F. 1967. Notes on algal nomenclature. V. Various Chlorophyceae and Rhodophyceae. Phykos 5: 95-105.

Pizarro, A. 1986. Conocimiento actual y avances recientes sobre el manejo y cultivo de Gracilaria en Chile. Monografías Biológicas 4: 63-96.

Ramírez, M. E. \& L. TAPIA. 1991. Gracilariopsis lemaneiformis (Bory) Dawson, Acleto et Foldvik en el norte de Chile (Rhodophyta, Gracilariaceae). Revista Chilena de Historia Natural 64: 323 - 330.

RENFREW, D. E. 1983. An investigation of the taxonomic relationship between Gracilaria tikvahiae McLachlan and Gracilaria bursa-pastoris (Gemel.) Silva. Master's Thesis, Acadia University, Wolfville, Nova Scotia, Canada. 198 pp.

Romo, H., K. Alveal \& V. Dellarossa. 1979. Biología de Gracilaria verrucosa (Hudson) Papenfuss en Chile central. Actas Symp. Algas Mar. Chilenas 1: $155-163$

SAntelices, B. 1989. Algas Marinas de Chile. Distribución, Ecología, Utilización y Diversidad. Ediciones Universidad Católica de Chile, Santiago. pp. 399.

SANTElices, B. \& R. Ugarte. 1990. Ecological differences among Chilean populations of commercial Gracilaria. J. appl. Phycol. 2: 17-26.

Searles, R. B., G. L. Leister \& J. F. Brauner. 1974. Seaweeds of southern South America. Antarc. J. US 9: 23-24.

SOKAL, R.R. \& F.J. RohlF. 1981. Biometry. The Principles and Practice of Statistics in Biological Research. W.H. Freeman and Company, San Francisco, 859 pp.

Yамамото, H. 1978. Systematic and Anatomical Study of the genus Gracilaria in Japan. Mem. Fac. Fish. Hokkaido Univ. 25: 97-141.

Fecha de recepción: 06.04.06

Fecha de aceptación: 01.08.06 